\title{
CK2-Dependent Phosphorylation of the Brg1 Chromatin Remodeling Enzyme Occurs during Mitosis
}

\author{
Teresita Padilla-Benavides ${ }^{1}{ }^{\circledR}$, Dominic T. Haokip ${ }^{1}$, Yeonsoo Yoon ${ }^{2}$, Pablo Reyes-Gutierrez ${ }^{1}{ }^{1}$, \\ Jaime A. Rivera-Pérez ${ }^{2}$ and Anthony N. Imbalzano ${ }^{1, *}$ \\ 1 Department of Biochemistry and Molecular Pharmacology, University of Massachusetts Medical School, \\ Worcester, MA 01605, USA; teresita.padilla@umassmed.edu (T.P.-B.); domlenz62@gmail.com (D.T.H.); \\ Pablo.ReyesGutierrez@umassmed.edu (P.R.-G.) \\ 2 Department of Pediatrics, Division of Genes and Development, University of Massachusetts Medical School, \\ Worcester, MA 01655, USA; yeonsoo.yoon@umassmed.edu (Y.Y.); jaime.rivera@umassmed.edu (J.A.R.-P.) \\ * Correspondence: Anthony.imbalzano@umassmed.edu; Tel.: +1-508-856-1029
}

Received: 27 November 2019; Accepted: 27 January 2020; Published: 30 January 2020

\begin{abstract}
Brg1 (Brahma-related gene 1) is one of two mutually exclusive ATPases that can act as the catalytic subunit of mammalian SWI/SNF (mSWI/SfigureNF) chromatin remodeling enzymes that facilitate utilization of the DNA in eukaryotic cells. Brg1 is a phospho-protein, and its activity is regulated by specific kinases and phosphatases. Previously, we showed that Brg1 interacts with and is phosphorylated by casein kinase 2 (CK2) in a manner that regulates myoblast proliferation. Here, we use biochemical and cell and molecular biology approaches to demonstrate that the Brg1-CK2 interaction occurred during mitosis in embryonic mouse somites and in primary myoblasts derived from satellite cells isolated from mouse skeletal muscle tissue. The interaction of CK2 with Brg1 and the incorporation of a number of other subunits into the mSWI/SNF enzyme complex were independent of CK2 enzymatic activity. CK2-mediated hyperphosphorylation of Brg1 was observed in mitotic cells derived from multiple cell types and organisms, suggesting functional conservation across tissues and species. The mitotically hyperphosphorylated form of Brg1 was localized with soluble chromatin, demonstrating that CK2-mediated phosphorylation of Brg1 is associated with specific partitioning of Brg1 within subcellular compartments. Thus, CK2 acts as a mitotic kinase that regulates Brg1 phosphorylation and subcellular localization.
\end{abstract}

Keywords: Brg1; SMARCA4; casein kinase 2; phosphorylation; mitosis; chromatin remodeling enzyme; cell proliferation; myoblasts

\section{Introduction}

The mammalian SWI/SNF (SWItch/Sucrose Non-Fermentable; mSWI/SNF) complexes belong to a family of chromatin-remodeling enzymes that utilize ATP to modify chromatin structures and DNA/histone contacts [1-3]. These chromatin remodelers can either promote or inhibit the accessibility of various factors that control gene transcription, replication, recombination, and repair [4-6]. The enzymatic activity of the mSWI/SNF complexes are driven by the ATPase Brahma-related gene 1 (Brg1) or Brahma (Brm) [2,7-9]. There are many associated subunits that combine in an ordered manner [10] to form different subfamilies of complexes that contain both common and unique subunits [10-14]. The great diversity of enzyme complex assemblies is thought to enable cell- and developmental stage-specific functions [14,15]. 
We and others have shown that the activity of Brg1 and other components of the mSWI/SNF complex is post-translationally regulated by various signaling pathways [16-22]. For instance, in the liver, BAF60c phosphorylation via the insulin-signaling pathway enables the expression of lipogenic genes [23]. In cardiac muscles, the DPF/BAF45c subunit is phosphorylated in response to hypertrophic signaling [19]. The catalytic subunit Brg1 is phosphorylated upon DNA-damage signaling by the ataxia telangiectasia-mutated kinase, resulting in the binding of the ATPase to nucleosomes containing $\gamma-\mathrm{H} 2 \mathrm{AX}$ to enable repair centers [24]. In Drosophila, where there is only one catalytic subunit, phosphorylation by cyclin-dependent kinases is needed for cell proliferation and development of wing epithelium [25]. Studies of skeletal muscle differentiation showed that the BAF60c subunit is phosphorylated by the mitogen-activated protein kinase p38, which allows the assembly of the rest of the mSWI/SNF complex at myogenic promoters $[18,26]$. mSWI/SNF enzymes are required for myoblast proliferation and at multiple stages of differentiation [27-32]. Regulated phosphorylation and dephosphorylation of Brg1 is an essential part of both proliferation and differentiation $[16,17,22]$. Phosphorylation of Brg1 by protein kinase $C \beta 1$ (PKC $\beta 1$ ) prior to the induction of differentiation signaling has a repressive effect on the function of Brg1 and leads to a block of myogenic differentiation [16]. However, dephosphorylation of Brg1 by the phosphatase calcineurin opposes the activity of PKC $\beta 1$, allowing chromatin remodeling by Brg1 and initiation of myogenesis [16]. Mutagenesis and unbiased mass spectrometry analyses of Brg1 phosphopeptides in the presence and absence of a calcineurin inhibitor identified calcineurin target sequences, but the mass spectrometry data identified additional Brg1 phosphopeptides that were not responsive to calcineurin inhibition [16]. This suggests that Brg1 is a target of additional signal transduction pathways. Our subsequent studies showed that Brg1 was phosphorylated by casein kinase 2 (CK2), a serine/threonine kinase, which promoted myoblast proliferation and survival by regulating subnuclear localization and incorporation of one of two related subunits, BAF155/BAF170, into the enzyme complex [17].

CK2 is ubiquitously expressed and functions as a tetramer of two catalytic subunits, CK2 $\alpha$ or $\mathrm{CK} 2 \alpha^{\prime}$, and two CK2 $\beta$ regulatory subunits, and it has more than 300 known substrates [33-35]. CK2 is required for cell cycle progression, survival, apoptosis, and transcriptional regulation. Knockout mice lacking the $\mathrm{CK} 2 \alpha$ subunit show cardiac and neural tube defects and die during embryogenesis, whereas mice lacking the $\alpha^{\prime}$ subunit have impaired spermatogenesis [36-38]. Knockout of the CK2 $\beta$ subunit in mice leads to reduced proliferation during embryogenesis, which is reflected in the small size of the animals at embryonic day 6.5 (E6.5) and resorption at E7.5 [39]. Analyses of a murine conditional knockout model showed that CK2 $\beta$ is essential for viability of embryonic stem cells and primary embryonic fibroblasts [39]. In vitro cell experiments have shown that CK2 inhibition results in cell cycle blockage and death [40-43]. Thus, CK2 has been associated with proliferation, lineage determination, and differentiation of various tissues, including skeletal muscle [44].

CK2-mediated regulation of myoblasts occurs at multiple levels. For instance, transcription factors from the myogenic regulatory factor (MRF) family and paired box (Pax) 3 and 7 are directly or indirectly regulated by CK2 activity [17,45-52]. These proteins are necessary for the proliferation and/or differentiation of muscle-specific precursor cells [46,53-58]. In vivo studies showed that the CK2 $\alpha^{\prime}$-depleted mice have a similar muscular constitution as wild-type animals [38,59]. However, these $\mathrm{CK} 2 \alpha^{\prime}$ knockout mice showed altered regeneration of skeletal muscles due to the dysregulation of the cell cycle, which resulted in muscle fibers of reduced sizes [59]. Furthermore, muscles of mice depleted of the CK2 $\beta$ subunit presented with compromised muscle endplate structure and function, and consequently, the differentiated fibers showed a myasthenic phenotype [60]. In vitro studies using $\mathrm{C} 2 \mathrm{C} 12$ cells showed that each of the CK2 enzyme subunits contributed to the determination of the skeletal muscle lineage. CK2 $\beta$ contributed to myoblast commitment and muscle-specific gene expression, as it is essential for MyoD expression in proliferating myoblasts [61]. CK2 $\alpha$ was required for the activation of the muscle-specific gene program [61]. CK2 $\alpha^{\prime}$ regulated myoblast fusion by facilitating membrane translocation of fusogenic proteins, such as myomixer [61]. 
Previous work from our group showed that Brg1 is required for the proliferation of primary myoblasts derived from mouse satellite cells, because it binds to and remodels chromatin at the Pax7 promoter and activates its expression [28]. Pax7 is the master transcriptional regulator for proliferation of the muscle satellite cells [62-65]. Pax7 knockout mice have a reduced pool of satellite cells that are gradually lost with age, impairing the animal's capabilities to regenerate muscle tissues $[53,54,57,66]$. We showed that overexpression of Pax7 in primary myoblasts lacking Brg1 rescues the cells from apoptosis and restores proliferation, indicating that Brg1 regulates Pax7 expression to promote primary myoblast survival and proliferation [28]. Furthermore, we showed that Brg1 is phosphorylated by CK2 in proliferating primary myoblasts and that CK2 inhibition impaired Brg1 chromatin remodeling and transcriptional activity at the Pax7 locus [17]. In addition, phosphorylation of Brg1 by CK2 correlated with the subunit composition of the mSWI/SNF enzyme complex and its subnuclear localization [17].

Here, we report novel findings about Brg1 phosphorylation by CK2. We found that co-localization between CK2 and Brg1 occurred only in cells undergoing mitosis in developing somites of mouse embryos and in primary myoblasts isolated from satellite cells. Co-immunoprecipitation from primary myoblasts in $\mathrm{M}$ phase confirmed the association of Brg1 with CK2. The interaction between CK2 and Brg1, or other mSWI/SNF subunit proteins in mitotic cells, was independent of CK2 enzymatic activity, whereas localization to soluble chromatin required CK2 enzymatic function. Importantly, CK2-dependent hyperphosphorylation of Brg1 was conserved across different cell lineages. We note that prior work showed phosphorylation of Brg1 during M phase by extracellular signal-regulated kinases (ERKs) $[67,68]$, which therefore indicates multiple protein kinases act on Brg1 during mitosis.

\section{Results}

\subsection{Brg1 and CK2 Co-Localize in Mitotic Cells in Developing Somites of Mouse Embryos}

Work from our group and many others have demonstrated that CK2 is implicated in myoblast function [17,45-52,59-61]. Specifically, we demonstrated that CK2 modulates the ability of Brg1 to promote myoblast proliferation by inducing Pax7 expression [17]. To corroborate our studies in vivo, we investigated the interaction between CK2 and Brg1 in murine embryonic somite development. Somites are fast-dividing paired blocks of paraxial mesoderm that are the source of the sclerotome, myotome, and dermatome, which give rise to bone, muscle, and the dermis, respectively. Confocal microscopy analyses confirmed that Brg1 and CK2 are expressed in somitic cells from E9.5 mice (Figure 1). As expected, Brg1 localization was nuclear, and CK2 localization was predominantly, but not exclusively, cytoplasmic. Strikingly, little or no co-localization between these proteins was detected in interphase cells; however, clear co-localization of Brg1 and CK2 was detected in mitotic cells (Figure 1; lower panel, white arrows). Mitotic cells were marked by the detection of condensed chromosomes stained with phosphorylated histone $\mathrm{H} 3$ ( $\mathrm{PHH} 3$ ). In order to further investigate the Brg1-CK2 interaction during the progression of mitosis, we used an in vitro model of cultured primary myoblasts derived from mouse satellite cells. Images of mitotic cells from an asynchronous cell population were collected, with staining by PHH3 to mark the different stages of mitosis. Co-localization between Brg1 and CK2 was observed first at prometaphase and continued until late-telophase (Figure 2). 


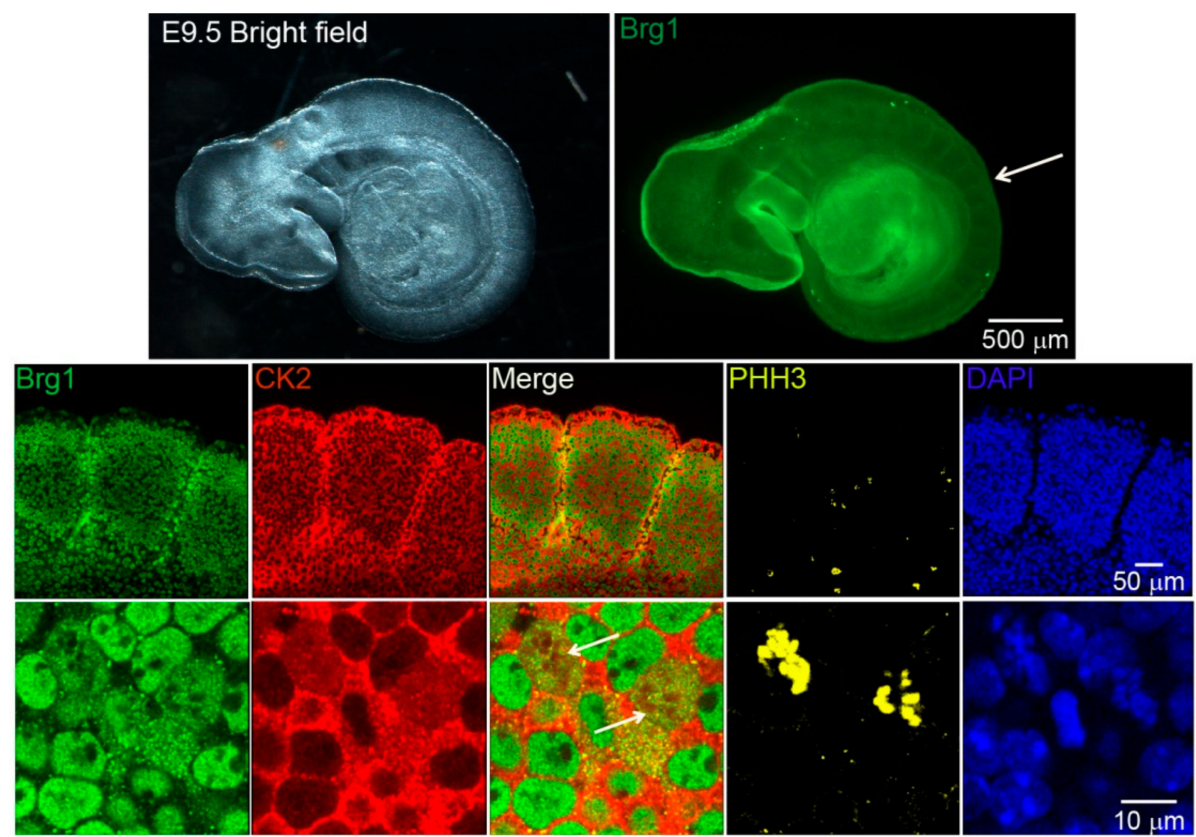

Figure 1. Casein kinase 2 (CK2) and Brahma-related gene 1 (Brg1) co-localize in mitotic cells of developing somites in mouse embryos. Representative confocal microscopy images from mice embryos showing the expression of Brg1 (green), CK2 (red), and phosphorylated histone H3 (PHH3, yellow) in somites of embryonic day 9.5 (E9.5) mice. The nuclei were stained with DAPI (blue). The white arrow in the upper panel points to the area of enlargement in the lower panels. The white arrows in the lower panel point to mitotic cells. Three different embryos were analyzed. 


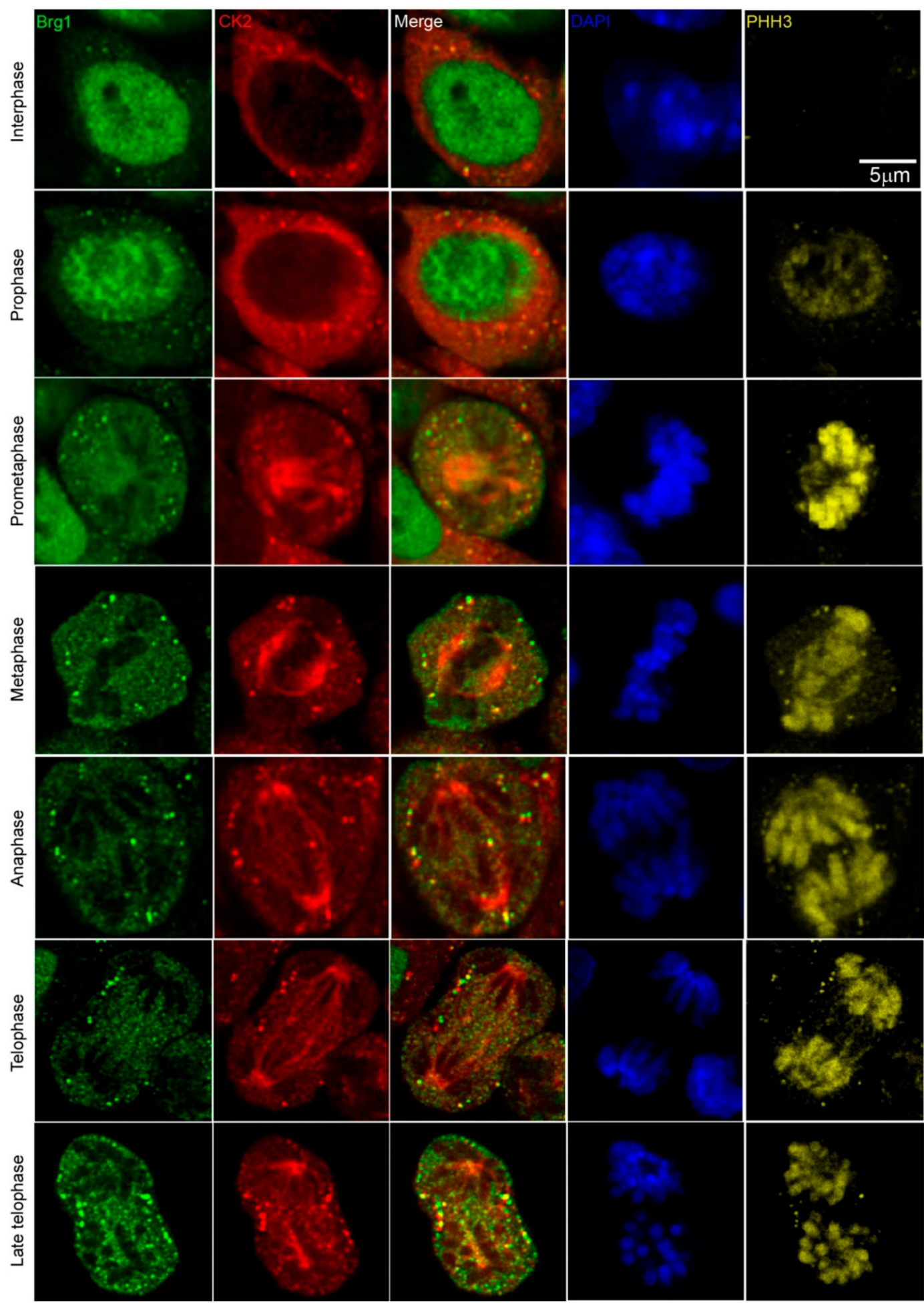

Figure 2. CK2 and Brg1 co-localize in mitotic primary myoblasts derived from mouse satellite cells. Representative confocal microscopy images from three independent biological replicates show the expression of Brg1 (green), CK2 (red), and phosphorylated histone H3 (PHH3, yellow) in proliferating primary myoblasts. The nuclei were stained with DAPI (blue).

\subsection{Pharmacological Inhibition of CK2 Activity Does not Impair Its Interaction with Brg1}

To facilitate biochemical studies of mitotic cells, we treated cycling primary myoblasts with nocodazole, a commonly used inhibitor of microtubule polymerization that results in cell cycle arrest at mitosis [69]. Flourescence-activated cell sorting (FACS) analysis of control or treated cells demonstrates 
the enrichment in the G2/M population that was obtained in the presence of nocodazole (Figure 3A). Our previous study addressed the effects of the specific CK2 inhibitor 4,5,6,7-tetrabromobenzotriazole (TBB) [70] on the proliferation capabilities of primary myoblasts derived from satellite cells and on the properties of Brg1 and the mSWI/SNF complex in treated cells [17]. We again made use of TBB to determine whether the CK2-Brg1 interaction required the enzymatic activity of CK2. Reciprocal co-immunoprecipitations showed that in control and in nocodazole-synchronized mitotic myoblasts, Brg1 and CK2 interacted as expected (Figure 3B). The interaction was maintained even when CK2 was inhibited by TBB (Figure 3B), demonstrating that the enzymatic activity of CK2 is not necessary for the formation of a stable complex containing Brg1 and CK2.

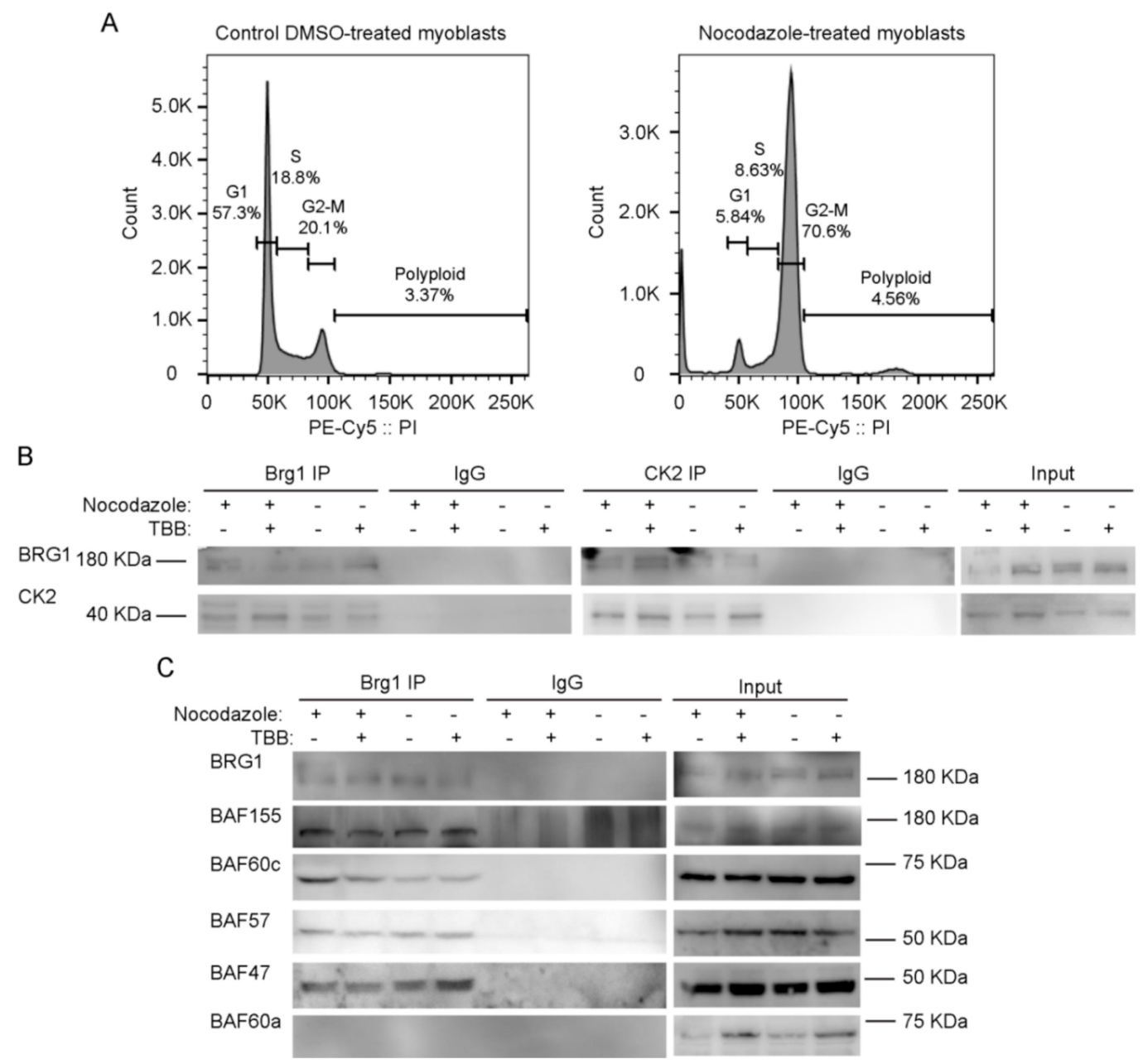

Figure 3. Inhibition of CK2 enzymatic activity does not impair its interaction with Brg1 or affect the interaction of Brg1 with numerous mammalian SWItch/Sucrose Non-Fermentable (mSWI/SNF) complex proteins. Primary myoblasts were treated or not with $500 \mathrm{nM}$ nocodazole and $10 \mu \mathrm{M}$ tetrabromobenzotriazole (TBB). (A) Representative fluorescence-activated cell sorting (FACS) analyses of primary myoblasts treated or not with nocodazole. (B) Representative Western Blots from a reciprocal immunoprecipitations of Brg1 (left panel) or CK2 (middle panel). IgG inputs (IPs) and input (1\%) for both proteins are shown as controls. (C) Representative Western Blots of Brg1 immunoprecipitation and Western Blots for the mSWI/SNF subunits BAF155, BAF60c, BAF57, BAF47, and BAF60a. IgG and inputs ( $2 \%$ ) for all samples were included as controls. Three independent biological replicates were performed.

\subsection{CK2 Inhibition Does not Impair the Interaction of Brg1 with Additional Subunits of the mSWI/SNF Complex}

We next asked whether the interaction of Brg1 with other mSWI/SNF subunits was dependent on the enzymatic activity of CK2. Immunoprecipitation assays for Brg1 from control and nocodazole-treated 
myoblasts showed a co-immunoprecipitation of Brg1 with BAF155, BAF60c, BAF57, and BAF47 in the presence or absence of TBB (Figure 3C). BAF60a, a homolog of BAF60c that is poorly or not incorporated in $\mathrm{mSWI} / \mathrm{SNF}$ complexes in skeletal muscle [71], was used as a negative control (Figure 3C). These data indicate that CK2 enzymatic activity is not required for the association of the indicated subunits with Brg1. The data do not address whether the different subfamilies of mSWI/SNF complexes contain all known components in the presence of TBB; however, the data suggest that mSWI/SNF enzyme complexes are not prevented from forming because of the inhibition of CK2 enzymatic activity.

\subsection{Brg1 is Hyperphosphorylated by CK2 during Mitosis}

Though we have provided numerous lines of evidence for CK2-mediated phosphorylation of Brg1 [17], there is an expectation that hyperphosphorylation of Brg1 might be visible in a Western Blot. However, this has been complicated by the large size of the Brg1 protein, the large number of identified and potential phosphorylation sites on Brg1, and the diversity of kinases that act or might be predicted to act on Brg1. Definitive evidence of hyperphosphorylation due to CK2 in conventional SDS-PAGE has been elusive. Therefore, we chose to use Phos-Tag ${ }^{\mathrm{TM}_{-}}$-supplemented SDS-PAGE. Phos-Tag ${ }^{\mathrm{TM}}$ forms alkoxide-bridged dinuclear metal complexes that bind to phosphorylated proteins and enhance changes in the migration of phosphorylated proteins [72-74]. Figure 4A shows a Western Blot of nocodazole-synchronized cells where Brg1 migrated more slowly than Brg1 from TBB-treated and control cells. Determination of the relative electrophoretic mobility of Brg1 showed that the reduced migration observed in samples obtained from mitotic-enriched myoblasts was significant compared to the nontreated controls (Figure 4B). These data suggest an enrichment of CK2-mediated phosphorylation of Brg1 during mitosis. In vitro assays of Brg1 from nocodazole-treated cells showed that treatment with calf-intestinal alkaline phosphatase (CIP) increased the mobility of Brg1 in a Phos-Tag ${ }^{\mathrm{TM}}$ gel (Figure 4C; compare lanes 1 and 4). Addition of EDTA-chelated metals required for CIP activity prevented the increase in gel mobility, as expected (Figure 4C; lanes 1-4). Addition of purified CK2 restored the shift in mobility of Brg1 but not in the presence of TBB (Figure 4C; compare lanes 5 and 6). Quantification of the relative mobility of Brg1 in each sample is presented in Figure 4D, and the change in mobility due to changes in the phosphorylation state was statistically significant. The combination of approaches taken in Figure 4 demonstrates the dependence of the altered electrophoretic mobility of Brg1 on the catalytic activity of the CK2 kinase. 
A

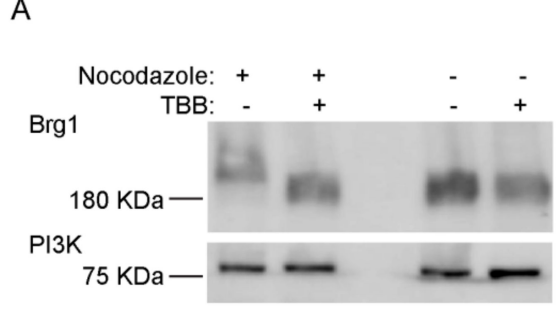

B

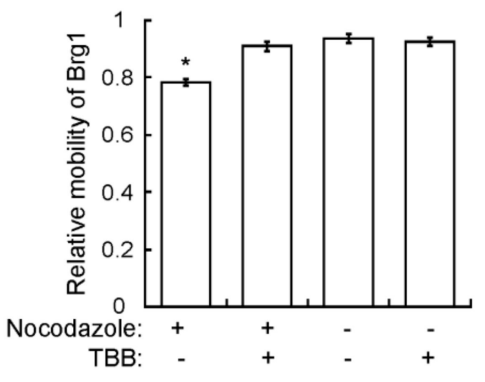

C

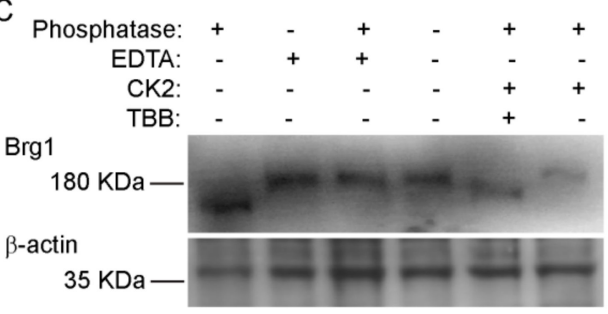

D

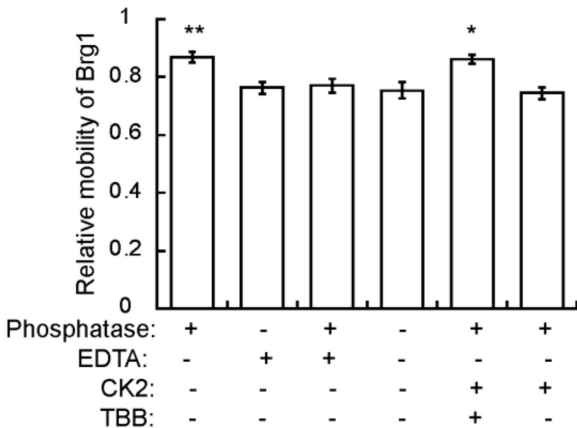

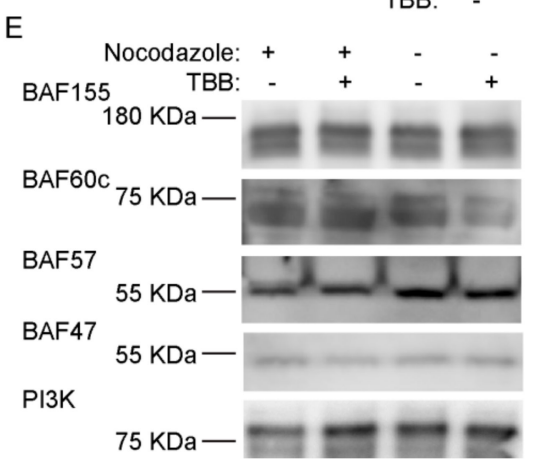

Figure 4. Brg1 is phosphorylated by CK2 during mitosis. Primary myoblasts were treated or not with $500 \mathrm{nM}$ nocodazole and $10 \mu \mathrm{M} \mathrm{TBB}$, as indicated. Samples were separated in a 5\% SDS-PAGE supplemented with Phos-TagTM. (A) Representative Western Blot of the CK2-mediated shift in Brg1 mobility in myoblast cultures enriched for mitotic cells. PI3K levels were monitored as a loading control. (B) Quantification of the average relative mobility of Brg1 in the gel in response to nocodazole treatment and CK2 inhibition $(n=3)$. (C) Representative Western Blots following an in vitro dephosphorylation/phosphorylation assay on Brg1 in primary myoblast extracts from cells treated as indicated. $\beta$-actin was monitored as a control. (D) Quantification of the average relative mobility of Brg1 in the gel in response to the treatments indicated in $(\mathbf{C})(n=3)$. (E) Representative Western Blots showing no easily discernible changes in mobility for BAF155, BAF60c, BAF57, or BAF47 in primary myoblast extracts from cells treated as indicated. PI3K was used as a loading control. Three independent biological replicates were performed for each experiment. Statistical significance was calculated by a t-test vs. the untreated control. ${ }^{*} p<0.05 ;{ }^{* *} p<0.01$.

We subsequently examined the mobility of the other subunits tested in Figure $3 \mathrm{C}$ on Phos-Tag ${ }^{\mathrm{TM}}$ gels. BAF155, BAF60c, and BAF57, but not BAF47, show two or more bands that are presumably due to differential phosphorylation (Figure 4E). No easily discernable changes in gel mobility were observed due to the presence of TBB. These data do not exclude the possibility that CK2 phosphorylates any of these $\mathrm{mSWI} / \mathrm{SNF}$ subunits, but the data do demonstrate that large mobility shifts such as that shown by the CK2-dependent phosphorylation of Brg1 do not occur in these other subunits.

\subsection{CK2 Phosphorylation of Brg1 during Mitosis is a Conserved Event in Different Mammalian Species and Tissues}

To determine whether the CK2-dependent phosphorylation of Brg1 during mitosis is part of a skeletal muscle-specific regulatory mechanism or is more widespread, we examined other cell types 
arrested in mitosis. We tested Brg1 gel mobility in Phos-Tag ${ }^{\mathrm{TM}}$ gels using Madin-Darby canine kidney (MDCK) epithelial cells, murine 3T3-L1 pre-adipocytes, murine C2C12 myoblasts, HeLa human cervical cancer cells, and human mammary epithelial MCF10A cells. Each of these are immortalized cell lines, in contrast to the primary cells tested in the experiments presented in Figures 1-4. HeLa cells are a transformed cancer cell line. Representative Western Blots from Phos-Tag ${ }^{\mathrm{TM}}$ gels show that in each cell type, Brg1 from cells grown in the presence of nocodazole migrated with reduced mobility, in contrast to the mobility observed in control cells (Figure 5). $\beta$-actin levels were monitored as a control. The reduced migration of Brg1 observed in samples enriched for mitotic cells was significant, as shown by the calculation of relative mobility in each of these cell lines (Figure $5 C-G$ ). These results suggest that CK2-dependent phosphorylation of Brg1 is a conserved event during mitosis of different cell types originating from different mammalian species.

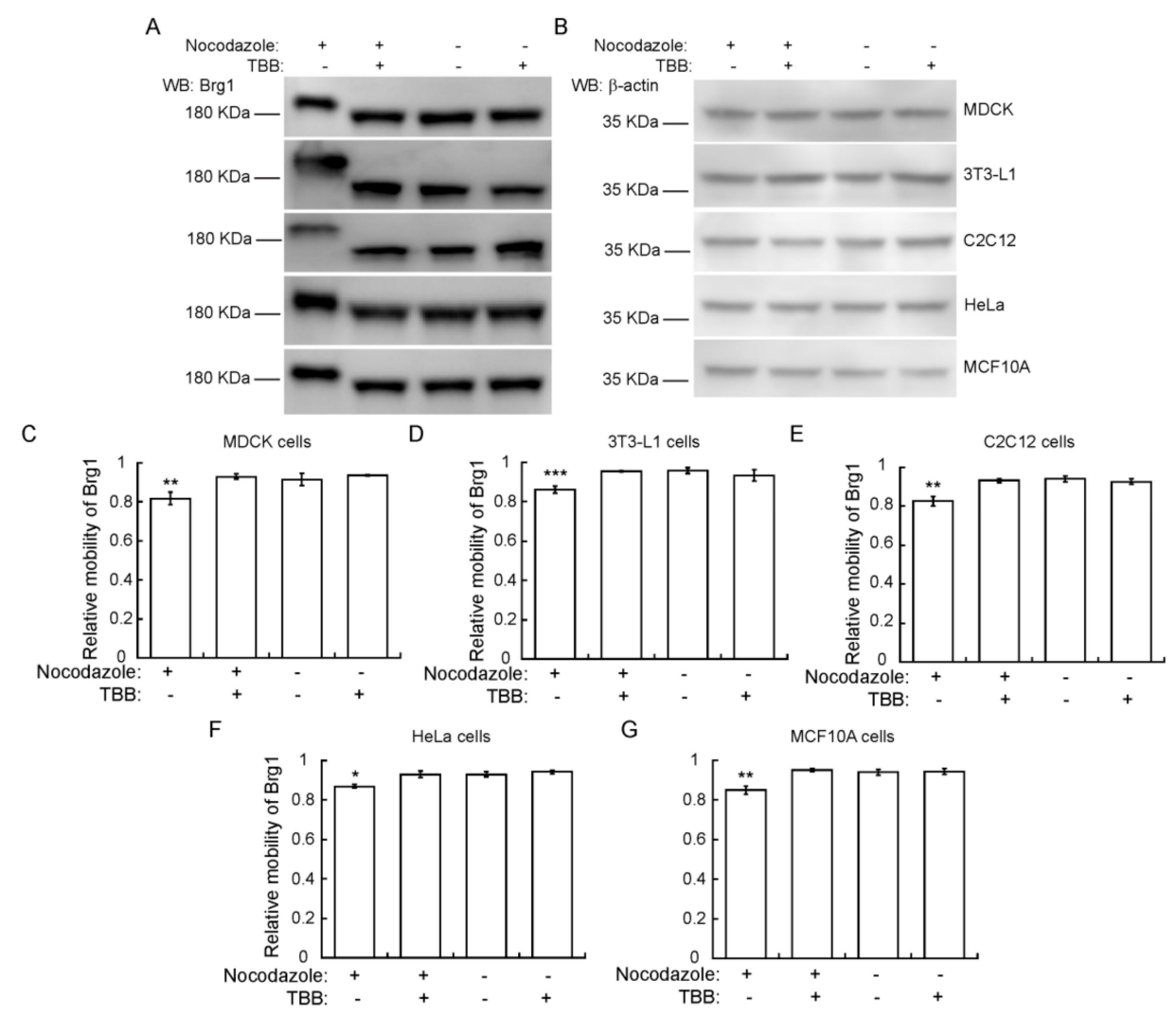

Figure 5. CK2-dependent phosphorylation of Brg1 in mitosis is a conserved event in different cell types and species. (A) Madin-Darby canine kidney (MDCK), 3T3-L1, C2C12, HeLa, and MCF10A cells were treated or not with cell type-specific concentrations of nocodazole, as indicated in Methods, and $10 \mu \mathrm{M}$ TBB where indicated. Samples were separated in a 5\% SDS-PAGE gel supplemented with Phos-Tag ${ }^{\mathrm{TM}}$ for Brg1 blots or by conventional SDS-PAGE for $\beta$-actin. Representative Western Blots of the mobility shift of Brg1 in extracts from cell cultures treated as indicated are shown, with $\beta$-actin expression from the same samples shown as a loading control (B). (C-G) Quantification of the average relative mobility of Brg1 in the gel in response to nocodazole treatment and CK2 inhibition of different cell lines. Three or more independent biological replicates were performed for each experiment. Statistical significance was calculated by a $t$-test vs. untreated controls. ${ }^{*} p \leq 0.05 ;{ }^{* *} p<0.01$.

\subsection{CK2 Enzymatic Activity is Required for Proper Sub-Cellular Partitioning of Brg1}

Nuclear fractionation experiments showed that Brg1 and other mSWI/SNF proteins are associated with both soluble chromatin and the nuclear matrix $[75,76]$, which is a nonchromatin fibrogranular ribonucleoprotein network within the nucleus [77]. The nuclear matrix provides an anchoring structure to chromatin loops, among other functions [78-80]. We previously demonstrated that Brg1 proteins 
containing phosphomimetic mutations at sites of CK2 activity lost the ability to associate with both soluble chromatin and the nuclear matrix, whereas Brg1 containing alanine substitutions at sites of CK2 activity that prevented phosphorylation associated only with the nuclear matrix [17]. We investigated the effects of CK2 inhibition on the localization of Brg1 in mitotic cells using a sequential extraction protocol that generates a cytosolic fraction, a soluble chromatin fraction, and, after a high salt wash, the nuclear matrix fraction [17,75,81]. A representative Western Blot of Brg1 from primary myoblasts is shown in Figure 6A. The hyperphosphorylated, or lower mobility, form of Brg1 from mitotic myoblasts was associated with the soluble chromatin fraction. In contrast, Brg1 associated with the nuclear matrix showed no alterations in gel mobility in all the conditions tested (Figure 6A). Representative control Western Blots showed the purity of the fractions (Figure 6B). Tubulin $\beta$ was found in the cytosolic fraction, lamin $\beta 1$ localized to the nuclear matrix, and RNA pol II was located in the soluble chromatin. The data indicate that Brg1 phosphorylated by CK2 in mitotic cells is associated exclusively with the soluble chromatin and is not associated with the nuclear matrix.
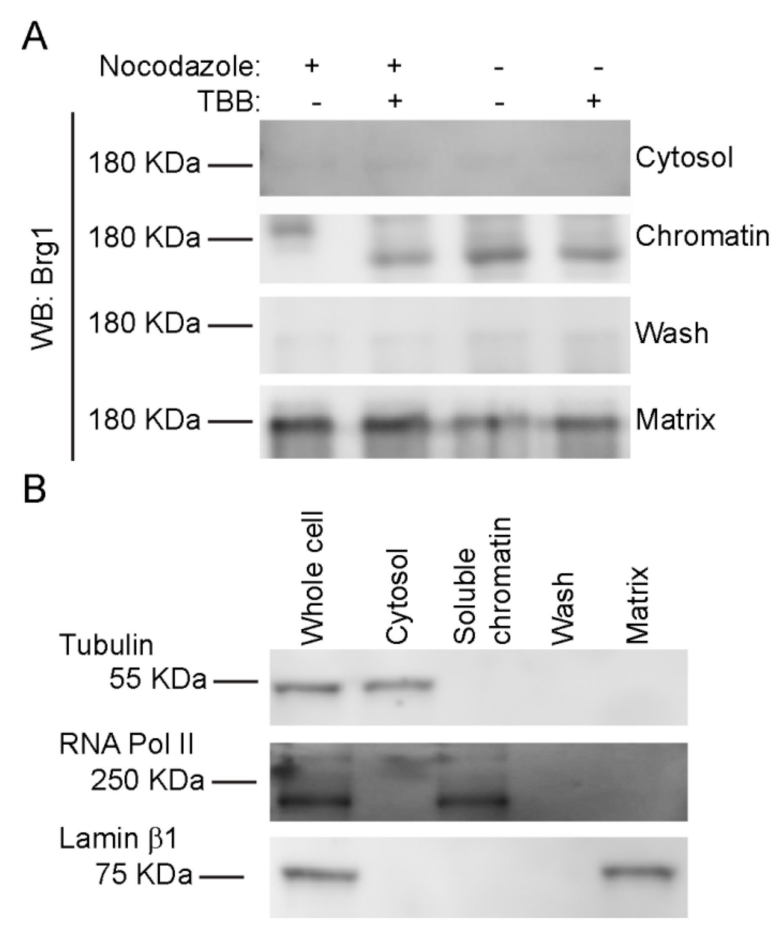

Figure 6. CK2-mediated phosphorylation of Brg1 is associated with soluble chromatin. Primary myoblasts were treated or not with $500 \mathrm{nM}$ nocodazole and $10 \mu \mathrm{M}$ TBB. (A) Representative Western Blots showing the sub-nuclear localization of Brg1. Samples were separated in a 5\% SDS-PAGE gel supplemented with Phos-Tag ${ }^{\mathrm{TM}}$. (B) Representative Western Blots demonstrating the purity of the fractions presented in (A). Tubulin is a marker for the cytosolic fraction, RNA Polymerase (Pol) II, the soluble chromatin fraction, and Lamin $\beta 1$, the nuclear matrix fraction. Three independent biological replicates were performed for each experiment.

\section{Discussion}

\subsection{Identification of CK2 as an M Phase Kinase for Brg1 Conserved across Mammalian Species and} Tissue Types

Post-translational modification of proteins comprising the mSWI/SNF chromatin remodeling enzymes is a mechanism to regulate function in addition to established mechanisms involving expression level of subunits, mutation of subunits, and diversity in the composition of enzyme complexes. We previously demonstrated that Brg1 is a substrate for CK2 that affects myoblast proliferation [17]. In the current work, we noted that Brg1 and CK2 co-localized only in mitotic cells in murine embryonic somites and in primary myoblasts derived from mouse satellite cells. These 
findings provide insight into the role of CK2-mediated phosphorylation of Brg1 by establishing that this post-translational modification occurs during a specific phase of the cell cycle. We therefore altered our experimental approach by enriching for a mitotic population of cells through addition of nocodazole, which inhibits microtubule polymerization and therefore blocks the separation of mitotic chromosomes during mitosis. This approach, in combination with the use of the Phos-Tag ${ }^{\mathrm{TM}}$ reagent [72-74], allowed us to reproducibly visualize an altered (reduced) electrophoretic migration of Brg1 in mitotic cell extracts for the first time. The dependence of this modification on CK2 was demonstrated by manipulation of CK2 activity in cells and in vitro, providing visual evidence of CK2-mediated phosphorylation of Brg1 to complement mutagenesis studies previously published [17]. Some of the other mSWI/SNF subunits also were examined for CK2-dependent altered electrophoretic mobility. Although multiple forms of several of those proteins were evident in the Western Blots, consistent with the established observation that most, if not all, of the mSWI/SNF proteins are phosphoproteins [82], there was no obvious effect of CK2 inhibition. This suggests that CK2 primarily targets Brg1 but does not exclude the possibility that other mSWI/SNF proteins are also modified.

Given that this work and our prior work examined the phosphorylation of Brg1 by CK2 in primary murine myoblasts derived from satellite cells, which are adult stem cells that promote post-natal skeletal muscle expansion and repair, it was important to ascertain whether this event was restricted to post-natal skeletal muscle or not. The co-localization of CK2 with Brg1 in mitotic mouse somites does not demonstrate CK2-mediated phosphorylation of Brg1 in embryonic tissue, but it is suggestive of function during embryonic development. More conclusive data was obtained by surveying a small assortment of cell lines for CK2-dependent phosphorylation of Brg1. Canine and human, in addition to murine cells, showed evidence of CK2-dependent phosphorylation of Brg1 in mitosis. The cell lines tested were derived from several different tissue types, and one was derived from a human tumor. Thus, we observed phosphorylation of Brg1 in mitotic primary, immortalized, and transformed cells from different tissue types. These results suggest conservation of function.

\subsection{The Role of CK2 as a Kinase for Brg1 during Mitosis}

The experiments presented here indicate that CK2 catalytic activity is not required for Brg1 and CK2 to associate, based on reciprocal co-immunoprecipitation experiments, and is also not required for Brg1 to associate with at least some of the other mSWI/SNF subunits in a complex. Evidence to date indicates a functional role for CK2 in myoblast proliferation, as well as in differentiation (reviewed above), likely due to the large number of CK2 substrates. The link between CK2-mediated phosphorylation of the Brg1 ATPase of mSWI/SNF chromatin remodeling enzymes and function is to date limited to myoblast proliferation, but the exact nature of this function remains unclear. Previously, we depleted primary myoblasts of endogenous Brg1 by introduction of Cre recombinase into primary myoblasts isolated from a Brg1 conditional mouse [83] and showed that myoblast proliferation and survival was compromised [28]. We then engineered a system to replace the endogenous Brg1 in such myoblasts with wild-type or mutant Brg1 to make functional assessments of specific Brg1 amino acids [16,17]. When we mutated predicted sites of CK2 activity on Brg1 by substituting glutamine to introduce phosphomimetic amino acids, myoblast proliferation and survival was compromised, as in the case of Brg1 depletion or introduction of catalytically inactive Brg1 [17]. Substitution with alanine to introduce nonphosphorylatable amino acids had no effect on rate of proliferation or survival, while inhibition of CK2 activity with TBB actually increased myoblast proliferation rate, suggesting that phosphorylation of Brg1 by CK2 negatively impacted proliferation and that a balance between phosphorylation and dephosphorylation at sites of CK2 activity is required for normal cell proliferation.

In the current work, we noted that CK2-mediated phosphorylation of Brg1 occurs in mitosis and that hyperphosphorylated Brg1 partitions with the soluble chromatin, not with the nuclear matrix. Our prior study showed that inhibiting CK2-mediated phosphorylation did not impact the ability of Brg1 to bind to and remodel chromatin at the Pax7 promoter in support of Pax7 gene expression and that Brg1 was restricted to the nuclear matrix under these conditions [17]. The results therefore 
suggest that CK2-mediated phosphorylation of Brg1 is not required for transcription-related functions, at least at the $\operatorname{Pax} 7$ locus. Instead, a Brg1 function related to the role of soluble chromatin during mitosis seems more likely. Does regulated CK2-mediated phosphorylation of Brg1 facilitate mitotic chromatin condensation? Or might the phosphorylation state of Brg1 be related to its ability to contribute to higher-order genome organization in the nucleus? Knockdown of Brg1 in proliferating MCF10A breast epithelial cells resulted in altered nuclear shapes [84], altered telomere organization, and a weakening of topologically associating domain (TAD) boundaries [85], implicating Brg1 as a necessary component for proper genome organization and nuclear structure $[86,87]$. Three-dimensional genome organization observed in interphase cells is profoundly altered in mitosis [88] via mechanisms involving condensin-mediated organization of chromatin loop arrays [89]. Perhaps CK2-mediated phosphorylation of Brg1 contributes to or is a consequence of this process. Precise identification of the exact Brg1 amino acids that are phosphorylated by CK2 would further our understanding and promote additional experimentation to explore their functions.

\subsection{CK2 and ERK Modifications of Brg1 during Mitosis}

Early work on the mSWI/SNF complex determined that most, if not all, of the subunit proteins were phosphoproteins [82], that Brg1 was a mitotic phosphoprotein [90], and that hyper-phosphorylation of Brg1 occurred during mitosis $[67,68]$. The hyperphosphorylation of Brg1 during mitosis was correlated with the dissociation of Brg1 from the condensing mitotic chromosomes $[67,68]$. Dephosphorylation of Brg1 was associated with the reassociation of BRG1 with chromatin as cells exited mitosis [67]. The mSWI/SNF complex purified from mitotic cells was inactive in in vitro chromatin remodeling assays, while mSWI/SNF complexes purified from cells exiting mitosis were active [67]. The kinase responsible for this activity has been investigated in vitro. Cdc2-cyclinB kinase did not phosphorylate Brg1 or other mSWI/SNF subunits [90]. However, a purified, active mSWI/SNF complex isolated from HeLa interphase cells could be treated with ERK1, a member of the mitogen-activated kinase (MAPK) family, resulting in Brg1 hyperphosphorylation and the inactivation of the chromatin remodeling activity of the mSWI/SNF complex. The data suggest that a MAPK phosphorylates Brg1 as a switch to control its chromatin remodeling activity and that the chromatin remodeling activity is inactivated as a cause or consequence of Brg1 exclusion from the condensing mitotic chromosomes.

The intersection of these data with the data presented about CK2-mediated phosphorylation of $\operatorname{Brg} 1$ is limited to two points. First is the observation that Brg1 was found associated with one or more other mSWI/SNF enzyme subunits in mitosis $[67,68]$ (Figure 3). Thus, many of the mSWI/SNF enzyme subunits remain in a complex during mitosis, apparently regardless of the phosphorylation state of Brg1. Second, observations about Brg1 phosphorylation from each of the studies directly indicate or at least suggest that they are conserved across different tissue types and, likely, across species $[67,68]$ (Figure 5). Though it is possible that either CK2 or MAPK could be sufficient for Brg1 phosphorylation during mitosis, the predicted sites of MAPK and CK2 phosphorylation activity are different, making it possible that different kinases act on Brg1 during mitosis. Whether kinases modifying Brg1 work in concert or independently, and whether each promotes the same or different functions, remains unknown. Nevertheless, the data collectively supports the concept that Brg1 and mSWI/SNF enzyme functions are dynamically regulated by phosphorylation during mitosis.

\section{Materials and Methods}

\subsection{Cell Culture}

\subsubsection{Murine Primary Myoblasts Derived from Satellite Cells}

Mice were housed in the animal care facility at the University of Massachusetts Medical School (Worcester, MA, USA) in accordance with the Institutional Animal Care and Use Committee guidelines. Mouse satellite cells were purified from whole-leg muscle from 3- to 6-week-old male and female 
wild-type C57B1/6 by differential plating following Percoll sedimentation, as previously described [91]. Isolated primary myoblasts were plated at $4 \times 10^{4}$ cells $/ \mathrm{cm}^{2}$ in growth media (GM) containing a 1:1 mix of DMEM and F-12 media; $20 \%$ fetal bovine serum (FBS); $2 \%$ chick embryo extract; $25 \mathrm{ng} / \mathrm{mL}$ recombinant basic fibroblastic growth factor (FGF, Millipore, Burlington, MA, USA); and $100 \mathrm{U} / \mathrm{mL}$ of penicillin/streptomycin.

\subsubsection{T3-L1 Murine Pre-Adipocytes}

Cells were plated at $2 \times 10^{4}$ cells $/ \mathrm{cm}^{2}$ and maintained at $<50 \%$ confluency in DMEM with high glucose, supplemented with $10 \%$ FBS and $100 \mathrm{U} / \mathrm{mL}$ of penicillin/streptomycin.

\subsubsection{Human MCF10A Breast Epithelium Cells}

Cells were plated at $1 \times 10^{5}$ cells $/ \mathrm{cm}^{2}$ in a mixture of DMEM/F12 (1:1, v:v), supplemented with $5 \%$ FBS, $100 \mathrm{U} / \mathrm{mL}$ penicillin/streptomycin, $0.5 \mu \mathrm{g} / \mathrm{mL}$ hydrocortisone, $10 \mu \mathrm{g} / \mathrm{mL}$ insulin, and $20 \mathrm{ng} / \mathrm{mL}$ epidermal growth factor (EGF).

\subsubsection{Murine C2C12 Myoblast Cells, Madin-Darby Canine Kidney (MDCK) Cells, and Human} Cervical Epithelial Adenocarcinoma HeLa Cells

Cells were plated at $1 \times 10^{5}$ cells $/ \mathrm{cm}^{2}$ in DMEM, supplemented with $10 \% \mathrm{FBS}$ and $100 \mathrm{U} / \mathrm{mL}$ of penicillin/streptomycin.

Where indicated, the cells were cultured in the presence or absence of nocodazole to induce cell cycle arrest in mitosis. The nocodazole concentrations and incubation times were: $500 \mathrm{nM}$ for $16 \mathrm{~h}$ for primary myoblasts obtained from C57Bl/6 mice and C2C12 cells [92], $300 \mathrm{nM}$ for $16 \mathrm{~h}$ for 3T3-L1 preadipocytes [93], $250 \mathrm{nM}$ for $24 \mathrm{~h}$ for MCF10A cells [94], $250 \mathrm{nM}$ for $16 \mathrm{~h}$ for HeLa cells [95], and $100 \mathrm{nM}$ for $11 \mathrm{~h}$ for MDCK cells [96]. CK2 was inhibited with $10 \mu \mathrm{M}$ of TBB, as described before [17]. Media was replaced every day.

\subsection{Antibodies}

The primary antibodies used were: rabbit anti-CKII $\alpha$ (2656), rabbit anti-BAF60c (62265), and rabbit anti-phospho-histone H3 (Ser10; D2C8) conjugated to Alexa Fluor 647 and were obtained from Cell Signaling Technologies. The rabbit anti-Brg1 (G-7), rabbit anti-BAF155 antibody (H-76), rabbit anti-lamin $\beta 1$ (H-90), and rabbit anti-pol II (N-20) were purchased from Santa Cruz Biotechnology. The rabbit anti-PI3K p85 antibody, N-SH2 domain (ABS233), was obtained from Millipore Corp. The rabbit anti-Ini1 (BAF47) antisera was previously described [29]. The rabbit anti-SMARCE1 (BAF57, A13353) and rabbit anti-SMARC1 (BAF60a, A6310) were obtained from Abclonal Technology. The secondary anti-mouse and anti-rabbit horseradish peroxidase-conjugated antibodies and the Alexa Fluor 488- and 555-conjugated antibodies were from Thermo Fisher Scientific.

\subsection{Embryo Collection and Whole Mount Immunostaining}

All animal experiments were conducted under the guidance of the Institutional Animal Care and Use Committee of the University of Massachusetts Medical School. CD-1 mice were obtained from Charles River Laboratories (Strain code 022). All animals were maintained on a $12 \mathrm{~h}$ light cycle. The middle of the light cycle of the day when a mating plug was observed was considered embryonic day 0.5 (E0.5) of gestation.

Embryos were collected at E9.5 and were fixed with phosphate-buffered 10\% formalin overnight at $4{ }^{\circ} \mathrm{C}$. The next day, the embryos were washed three times with PBS for $10 \mathrm{~min}$ and permeabilized with PBT buffer (0.5\% Triton-X100 in PBS) for $10 \mathrm{~min}$ at room temperature. Samples were incubated with blocking solution for $1 \mathrm{~h}$ (PBT, $5 \%$ horse serum) at room temperature. The embryos were incubated with the primary antibodies against CK2 and Brg1 (1:100) in blocking solution overnight at $4{ }^{\circ} \mathrm{C}$. The samples were then washed three times with PBT solution for $10 \mathrm{~min}$ at room temperature, then incubated with species-specific fluorescent secondary antibody (1:500) in PBT for $2 \mathrm{~h}$ at room temperature and 
washed three times with PBT solution for $10 \mathrm{~min}$ at room temperature. Samples were incubated with the anti-PHH3 antibody for $2 \mathrm{~h}$ at room temperature, followed by a $30 \mathrm{~min}$ incubation with 4',6-diamidino-2-phenylindole (DAPI). Negative controls were prepared as described above, but no primary antibodies were included. Embryos were washed three times with PBT at room temperature for $10 \mathrm{~min}$, and a final wash was performed with PBS for $10 \mathrm{~min}$ at room temperature. Embryos were equilibrated with sequential 15 min incubations of PBS:glycerol solutions (1:1, 1:2) and mounted in Vectashield containing DAPI (Vector Labs). Imaging was performed with a Leica TCS SP5 confocal laser scanning microscope (Leica) using a 40× water immersion objective.

\subsection{Primary Myoblast Immunofluorescence and Confocal Microscopy Analyses}

Proliferating myoblasts for immunofluorescence were grown on glass-bottom CELLview Advanced TC culture dishes (Grenier Bio-One, Kremsmünster, Austria). Cells were cultured in the presence or absence of $10 \mu \mathrm{M}$ TBB. Cells were fixed in phosphate-buffered $10 \%$ formalin, blocked in PBT buffer containing $5 \%$ horse serum, then incubated overnight at $4{ }^{\circ} \mathrm{C}$ with the anti-CK2 and anti-Brg1 primary antibodies diluted 1:100 in blocking buffer. Cells were washed three times with PBT buffer and sequentially incubated for $2 \mathrm{~h}$ with fluorescent labeled antibodies (1:500 dilution in blocking buffer). After three additional washes with PBT buffer, the cells were incubated with the anti-PHH3 antibody. Cells were counterstained with 4',6-diamidino-2-phenylindole (DAPI) and imaged with a Leica TCS SP5 confocal laser scanning microscope (Leica) using a 40× water immersion objective.

\subsection{Cell Cycle Analyses by Flow Cytometry}

Primary myoblasts were incubated with $500 \mathrm{nM}$ nocodazole for $16 \mathrm{~h}$. The cells then were washed in PBS to remove all traces of serum. The cell concentration was adjusted to $2 \times 10^{6}$ cells/ $/ 100 \mu \mathrm{L}$ in PBS, and $900 \mu \mathrm{L}$ of $95 \%$ ethanol were added dropwise to the cells while vortexing gently. Cells were stored at $4{ }^{\circ} \mathrm{C}$ for $24 \mathrm{~h}$. Then the cells were pelleted by centrifugation at $2000 \times g$, the ethanol was removed, and samples were washed once with PBS, centrifuged again, and PBS was removed. The cells subsequently were incubated for $20 \mathrm{~min}$ in the dark at $37^{\circ} \mathrm{C}$ in $1 \mathrm{~mL}$ of propidium iodide (PI) staining solution containing $900 \mu \mathrm{l}$ PBS, $2 \mathrm{mM} \mathrm{MgCl}_{2}, 50 \mu \mathrm{L}$ propidium iodide stock solution $(1 \mathrm{mg} / \mathrm{mL})$, and $50 \mu \mathrm{L}$ of RNase Stock Solution $(1 \mathrm{mg} / \mathrm{mL}$ ). Samples were analyzed by fluorescence-activated cell sorting at the Flow Cytometry Core at the University of Massachusetts Medical School.

\subsection{Western Blot Analyses}

Proliferating primary myoblasts were washed with ice-cold PBS and solubilized with RIPA buffer (10 mM PIPES, pH 7.4, $150 \mathrm{mM} \mathrm{NaCl}, 2$ mM EDTA, 1\% Triton X-100, 0.5\% sodium deoxycholate, and $10 \%$ glycerol) containing Complete Protease Inhibitor. Protein samples $(20-40 \mu \mathrm{g})$ were prepared for SDS-PAGE by boiling in Laemmli buffer. The resolved proteins were electro-transferred to PVDF membranes (Millipore, Burlington, MA, USA). The proteins of interest were detected with specific polyclonal or monoclonal antibodies, as indicated in the figures, followed by the species-appropriate peroxidase-conjugated antibodies (Thermo Fischer Scientific, Waltham, MA, USA) and chemiluminescent detection (Tanon ${ }^{\mathrm{TM}}$ High-sig ECL Western Blotting Substrate, Abclonal, Woburn, MA, USA). All Western Blotting experiments were performed using samples from three independent experiments. For the electrophoretic separation of phosphorylated proteins, samples were loaded in 5\% SDS-PAGE, supplemented with Phos-tag ${ }^{\mathrm{TM}}$ acrylamide (Wako, AAL-107) and $10 \mathrm{mM} \mathrm{MgCl}_{2}$, as indicated by the manufacturer. Relative mobility of proteins in gels is usually calculated as the ratio of the distance moved by the protein to the distance moved by the dye front. In our experiments, it was necessary to maximize the migration of Brg1 to separate the differently phosphorylated forms. Consequently, the dye front had run off the gel. We therefore standardized the electrophoresis by running for $3.5 \mathrm{~h}$ at 120 volts and used the ratio of the distance moved by Brg1 relative to the bottom of the gel. 


\subsection{Immunoprecipitation}

Cells were washed three times with ice-cold PBS and resuspended in lysis buffer ( $50 \mathrm{mM}$ Tris-HCl, pH 7.5, $150 \mathrm{mM} \mathrm{NaCl}, 1 \%$ Nonidet P-40, 0.5\% sodium deoxycholate, and Complete Protease Inhibitor). Cell extract $(250 \mu \mathrm{g})$ was incubated in a rotating mixer for $2 \mathrm{~h}$ with the anti-Brg1 or anti-CK2 primary antibodies at $4{ }^{\circ} \mathrm{C}$, followed by an overnight incubation with Pure Proteome Protein A/G mix magnetic beads (Millipore). Samples were washed as indicated by the manufacturer, and immunoprecipitated proteins were eluted with freshly prepared IP buffer $(10 \%$ glycerol, $50 \mathrm{mM}$ Tris- $\mathrm{HCl}, \mathrm{pH} 6.8$, and $1 \mathrm{M}$ $\mathrm{NaCl}$ ) by incubating for $1 \mathrm{~h}$ at room temperature on a rotating mixer. Samples were analyzed by SDS-PAGE and Western Blot.

\subsection{Brg1 Dephosphorylation and Phosphorylation Assays}

Dephosphorylation assays were performed with calf intestinal alkaline phosphatase (CIP; New England Biolabs). Briefly, $100 \mu \mathrm{g}$ of total protein extract from proliferating myoblasts were incubated with $1 \times \mathrm{CIP}$ buffer in the presence or absence of 50 units of phosphatase at $37^{\circ} \mathrm{C}$ for $1 \mathrm{~h}$; control experiments for CIP inhibition were performed simultaneously with $50 \mathrm{mM}$ EDTA. Then the phosphatase was heat-inactivated at $80^{\circ} \mathrm{C}$ for $10 \mathrm{~min}$ and samples were further incubated with CK2 in the presence or absence of the specific inhibitor tetrabromobenzotriazole (TBB, $10 \mu \mathrm{M})$ for $30 \mathrm{~min}$ at $30^{\circ} \mathrm{C}$. Reactions contained 50 units of CK2 (New England Biolabs, Ipswich, MA, USA), supplemented with $1 \times \mathrm{CK} 2$ reaction buffer $\left(20 \mathrm{mM}\right.$ Tris- $\mathrm{HCl}, 50 \mathrm{mM} \mathrm{KCl}, 10 \mathrm{mM} \mathrm{MgCl}_{2}$, and pH 7.5) and with $200 \mu \mathrm{M}$ ATP, as previously described [17]. Protein samples were separated with 5\% SDS-PAGE, supplemented with Phos-Tag ${ }^{\mathrm{TM}}$ acrylamide, as described above.

\subsection{Cell Fractionation}

Cell fractionation was performed according to the high-salt isolation protocol $[17,75,81]$. Briefly, proliferating primary myoblasts were washed with ice-cold PBS and extracted in cytoskeleton buffer (CSK: 10 mM PIPES, pH 6.8, $100 \mathrm{mM} \mathrm{NaCl}, 300 \mathrm{mM}$ sucrose, $3 \mathrm{mM} \mathrm{MgCl} 2,1 \mathrm{mM}$ EGTA, $1 \mathrm{mM}$ DTT, $0.5 \%(v / v)$ Triton X-100, and Complete Protease Inhibitor). The insoluble cytoskeletal fraction was isolated by centrifugation at $5000 \times \mathrm{g}$ for $3 \mathrm{~min}$. Chromatin was then solubilized by DNase I digestion ( 1 unit; New England Biolabs) in CSK buffer with Complete Protease Inhibitor for $15 \mathrm{~min}$ at $37^{\circ} \mathrm{C}$. The samples subsequently were incubated in $0.25 \mathrm{M}\left(\mathrm{NH}_{4}\right)_{2} \mathrm{SO}_{4}$ for $5 \mathrm{~min}$ at $4{ }^{\circ} \mathrm{C}$ and centrifuged at $5000 \times g$ for $3 \mathrm{~min}$. The pellet was washed with $2 \mathrm{M} \mathrm{NaCl}$ in CSK buffer for $5 \mathrm{~min}$ at $4{ }^{\circ} \mathrm{C}$ and centrifuged. The nuclear matrix contained in this final pellet was solubilized in $8 \mathrm{M}$ urea buffer. Fractions were analyzed by SDS-PAGE and Western Blotting; antibodies against RNA polymerase II, $\beta$ tubulin, and lamin $\beta 1$ were used as controls for purity of the fractions.

\subsection{Statistics}

All experiments were performed three or more times. The data are presented as the mean \pm SEM or SD, as indicated in the figures and legends. The statistical significance of quantified data was determined by a two-tailed Student's $t$-test. KaleidaGraph software version 5.4.3 (Synergy) was used for all statistical analyses. $p \leq 0.05$ was considered significant.

\section{Conclusions}

CK2 interacts with and phosphorylates the Brg1 chromatin remodeling enzyme during mitosis, which modulates cell proliferation. Hyperphosphorylation of Brg1 during mitosis was conserved in a range of mammalian cell types and the hyperphosphorylated form was localized in the soluble chromatin. This work provides evidence that CK2 is a mitotic kinase that phosphorylates Brg1 and regulates its sub-cellular localization and function. 
Author Contributions: Conceptualization, A.N.I.; methodology, T.P.-B., D.T.H., Y.Y., P.R.-G., J.A.R.-P., and A.N.I.; software, T.P.-B. and A.N.I.; validation, T.P.-B., D.T.H., P.R.-G., and A.N.I.; formal analysis, T.P.-B. and A.N.I.; investigation, T.P.-B., D.T.H., Y.Y., and P.R.-G.; resources, T.P.-B., J.A.R.-P., and A.N.I.; data curation, T.P.-B., D.T.H., and A.N.I.; writing—original draft preparation, T.P.-B. and A.N.I.; writing—review and editing, T.P.-B., D.T.H., Y.Y., P.R.-G., J.A.R.-P., and A.N.I.; visualization, T.P.-B., D.T.H., and P.R.-G.; supervision, A.N.I.; project administration, A.N.I.; and funding acquisition, T.P.-B., J.A.R.-P., and A.N.I. All authors have read and agreed to the published version of the manuscript.

Funding: This work was supported by NIH grants GM56244 to ANI and HD083311 to J.A.R.-P. T.P.-B was partially supported by the Faculty Diversity Scholars Program award from the University of Massachusetts Medical School.

Acknowledgments: The authors thank Jeffrey Nickerson for discussion, Hanna Witwicka for comments on the manuscript, and Carol Schrader for support with cell cytometry analyses.

Conflicts of Interest: The authors declare no conflicts of interest.

$\begin{array}{ll}\text { Abbreviations } \\ \text { CK2 } & \text { Casein kinase 2 } \\ \text { Brg1 } & \text { Brahma-related gene-1 } \\ \text { SWI/SNF } & \text { SWItch/Sucrose Non-Fermentable } \\ \text { BRM } & \text { Brahma } \\ \text { PKC } \beta 1 & \text { Protein Kinase C } \beta 1 \\ \text { BAF } & \text { BRG1-Associated Factor } \\ \text { DPF } & \text { Double PHD Fingers 3 } \\ \gamma \text { H2AX } & \text { H2A histone family member X } \\ \text { MRF } & \text { Myogenic regulatory factors } \\ \text { Pax } & \text { Paired box } \\ \text { ERK } & \text { Extracellular signal-regulated kinase } \\ \text { FACS } & \text { Fluorescence activated cell sorting } \\ \text { MDCK } & \text { Madin Darby Canine Kidney } \\ \text { SDS/PAGE } & \text { Sodium dodecyl sulfate/polyacrylamide gel electrophoresis } \\ \text { MAPK } & \text { Mitogen-activated protein kinase } \\ \text { FBS } & \text { Fetal bovine serum } \\ \text { DMEM } & \text { Dulbecco's Modified Eagle Media } \\ \text { FGF } & \text { Fibroblast growth factor } \\ \text { DAPI } & \text { 4',6-diamidino-2-phenylindole } \\ \text { CIP } & \text { Calf intestine phosphatase } \\ \text { TBB } & \text { 4,5,6,7-Tetrabromobenzotriazole } \\ \text { DTT } & \text { dithiothreitol } \\ \text { EDTA } & \text { Ethylenediaminetetraacetic acid } \\ \text { CSK } & \text { Cytoskeleton buffer } \\ \end{array}$

\section{References}

1. Kwon, H.; Imbalzano, A.N.; Khavari, P.A.; Kingston, R.E.; Green, M.R. Nucleosome disruption and enhancement of activator binding by a human sw1/snf complex. Nature 1994, 370, 477-481. [CrossRef] [PubMed]

2. Wang, W.; Cote, J.; Xue, Y.; Zhou, S.; Khavari, P.A.; Biggar, S.R.; Muchardt, C.; Kalpana, G.V.; Goff, S.P.; Yaniv, M.; et al. Purification and biochemical heterogeneity of the mammalian swi-snf complex. EMBO J. 1996, 15, 5370-5382. [CrossRef] [PubMed]

3. Imbalzano, A.N.; Kwon, H.; Green, M.R.; Kingston, R.E. Facilitated binding of tata-binding protein to nucleosomal DNA. Nature 1994, 370, 481-485. [CrossRef] [PubMed]

4. Tyagi, M.; Imam, N.; Verma, K.; Patel, A.K. Chromatin remodelers: We are the drivers!! Nucleus 2016, 7, 388-404. [CrossRef]

5. Paul, S.; Bartholomew, B. Regulation of atp-dependent chromatin remodelers: Accelerators/brakes, anchors and sensors. Biochem. Soc. Trans. 2018, 46, 1423-1430. [CrossRef]

6. Rother, M.B.; van Attikum, H. DNA repair goes hip-hop: Smarca and chd chromatin remodellers join the break dance. Philos. Trans. R. Soc. Lond. Ser. B 2017, 372, 20160285. [CrossRef] 
7. Khavari, P.A.; Peterson, C.L.; Tamkun, J.W.; Mendel, D.B.; Crabtree, G.R. Brg1 contains a conserved domain of the swi2/snf2 family necessary for normal mitotic growth and transcription. Nature 1993, 366, 170-174. [CrossRef]

8. Muchardt, C.; Yaniv, M. A human homologue of saccharomyces cerevisiae snf2/swi2 and drosophila brm genes potentiates transcriptional activation by the glucocorticoid receptor. EMBO J. 1993, 12, 4279-4290. [CrossRef]

9. Chiba, H.; Muramatsu, M.; Nomoto, A.; Kato, H. Two human homologues of Saccharomyces cerevisiae swi2/snf2 and Drosophila brahma are transcriptional coactivators cooperating with the estrogen receptor and the retinoic acid receptor. Nucleic Acids Res. 1994, 22, 1815-1820. [CrossRef]

10. Mashtalir, N.; D'Avino, A.R.; Michel, B.C.; Luo, J.; Pan, J.; Otto, J.E.; Zullow, H.J.; McKenzie, Z.M.; Kubiak, R.L.; St Pierre, R.; et al. Modular organization and assembly of swi/snf family chromatin remodeling complexes. Cell 2018, 175, 1272-1288. [CrossRef]

11. Gatchalian, J.; Malik, S.; Ho, J.; Lee, D.S.; Kelso, T.W.R.; Shokhirev, M.N.; Dixon, J.R.; Hargreaves, D.C. A non-canonical brd9-containing BAF chromatin remodeling complex regulates naive pluripotency in mouse embryonic stem cells. Nat. Commun. 2018, 9, 5139. [CrossRef] [PubMed]

12. Michel, B.C.; D'Avino, A.R.; Cassel, S.H.; Mashtalir, N.; McKenzie, Z.M.; McBride, M.J.; Valencia, A.M.; Zhou, Q.; Bocker, M.; Soares, L.M.M.; et al. A non-canonical swi/snf complex is a synthetic lethal target in cancers driven by BAF complex perturbation. Nat. Cell Biol. 2018, 20, 1410-1420. [CrossRef] [PubMed]

13. Alpsoy, A.; Dykhuizen, E.C. Glioma tumor suppressor candidate region gene 1 (gltscr1) and its paralog gltscr1-like form swi/snf chromatin remodeling subcomplexes. J. Biol. Chem. 2018, 293, 3892-3903. [CrossRef] [PubMed]

14. Hargreaves, D.C.; Crabtree, G.R. Atp-dependent chromatin remodeling: Genetics, genomics and mechanisms. Cell Res. 2011, 21, 396-420. [CrossRef] [PubMed]

15. Wu, J.I. Diverse functions of atp-dependent chromatin remodeling complexes in development and cancer. Acta Biochim. Et Biophys. Sin. 2012, 44, 54-69. [CrossRef] [PubMed]

16. Nasipak, B.T.; Padilla-Benavides, T.; Green, K.M.; Leszyk, J.D.; Mao, W.; Konda, S.; Sif, S.; Shaffer, S.A.; Ohkawa, Y.; Imbalzano, A.N. Opposing calcium-dependent signalling pathways control skeletal muscle differentiation by regulating a chromatin remodelling enzyme. Nat. Commun. 2015, 6, 7441. [CrossRef]

17. Padilla-Benavides, T.; Nasipak, B.T.; Paskavitz, A.L.; Haokip, D.T.; Schnabl, J.M.; Nickerson, J.A.; Imbalzano, A.N. Casein kinase 2-mediated phosphorylation of brahma-related gene 1 controls myoblast proliferation and contributes to swi/snf complex composition. J. Biol. Chem. 2017, 292, 18592-18607. [CrossRef]

18. Simone, C.; Forcales, S.V.; Hill, D.A.; Imbalzano, A.N.; Latella, L.; Puri, P.L. P38 pathway targets swi-snf chromatin-remodeling complex to muscle-specific loci. Nat. Genet. 2004, 36, 738-743. [CrossRef]

19. Cui, H.; Schlesinger, J.; Schoenhals, S.; Tonjes, M.; Dunkel, I.; Meierhofer, D.; Cano, E.; Schulz, K.; Berger, M.F.; Haack, T.; et al. Phosphorylation of the chromatin remodeling factor dpf3a induces cardiac hypertrophy through releasing hey repressors from DNA. Nucleic Acids Res. 2016, 44, 2538-2553. [CrossRef]

20. Bourachot, B.; Yaniv, M.; Muchardt, C. Growth inhibition by the mammalian swi-snf subunit brm is regulated by acetylation. EMBO J. 2003, 22, 6505-6515. [CrossRef]

21. Wang, L.; Zhao, Z.; Meyer, M.B.; Saha, S.; Yu, M.; Guo, A.; Wisinski, K.B.; Huang, W.; Cai, W.; Pike, J.W.; et al. Carm1 methylates chromatin remodeling factor BAF155 to enhance tumor progression and metastasis. Cancer Cell 2014, 25, 21-36. [CrossRef] [PubMed]

22. Witwicka, H.; Nogami, J.; Syed, S.A.; Maehara, K.; Padilla-Benavides, T.; Ohkawa, Y.; Imbalzano, A.N. Calcineurin broadly regulates the initiation of skeletal muscle-specific gene expression by binding target promoters and facilitating the interaction of the swi/snf chromatin remodeling enzyme. Mol. Cell Biol. 2019, 39. [CrossRef] [PubMed]

23. Wang, Y.; Wong, R.H.; Tang, T.; Hudak, C.S.; Yang, D.; Duncan, R.E.; Sul, H.S. Phosphorylation and recruitment of BAF60c in chromatin remodeling for lipogenesis in response to insulin. Mol. Cell 2013, 49, 283-297. [CrossRef] [PubMed]

24. Kwon, S.J.; Park, J.H.; Park, E.J.; Lee, S.A.; Lee, H.S.; Kang, S.W.; Kwon, J. Atm-mediated phosphorylation of the chromatin remodeling enzyme brg1 modulates DNA double-strand break repair. Oncogene 2015, 34, 303-313. [CrossRef] 
25. Roesley, S.N.A.; La Marca, J.E.; Deans, A.J.; McKenzie, L.; Suryadinata, R.; Burke, P.; Portela, M.; Wang, H.; Bernard, O.; Sarcevic, B.; et al. Phosphorylation of Drosophila brahma on cdk-phosphorylation sites is important for cell cycle regulation and differentiation. Cell Cycle 2018, 17, 1559-1578. [CrossRef]

26. Forcales, S.V.; Albini, S.; Giordani, L.; Malecova, B.; Cignolo, L.; Chernov, A.; Coutinho, P.; Saccone, V.; Consalvi, S.; Williams, R.; et al. Signal-dependent incorporation of myod-BAF60c into brg1-based swi/snf chromatin-remodelling complex. EMBO J. 2012, 31, 301-316. [CrossRef]

27. De la Serna, I.L.; Carlson, K.A.; Imbalzano, A.N. Mammalian swi/snf complexes promote myod-mediated muscle differentiation. Nat. Genet. 2001, 27, 187-190. [CrossRef]

28. Padilla-Benavides, T.; Nasipak, B.T.; Imbalzano, A.N. Brg1 controls the expression of pax7 to promote viability and proliferation of mouse primary myoblasts. J. Cell. Physiol. 2015, 230, 2990-2997. [CrossRef]

29. De la Serna, I.L.; Ohkawa, Y.; Berkes, C.A.; Bergstrom, D.A.; Dacwag, C.S.; Tapscott, S.J.; Imbalzano, A.N. Myod targets chromatin remodeling complexes to the myogenin locus prior to forming a stable DNA-bound complex. Mol. Cell Biol. 2005, 25, 3997-4009. [CrossRef]

30. Ohkawa, Y.; Marfella, C.G.; Imbalzano, A.N. Skeletal muscle specification by myogenin and mef2d via the swi/snf atpase brg1. EMBO J. 2006, 25, 490-501. [CrossRef]

31. Ohkawa, Y.; Yoshimura, S.; Higashi, C.; Marfella, C.G.; Dacwag, C.S.; Tachibana, T.; Imbalzano, A.N. Myogenin and the swi/snf atpase brg1 maintain myogenic gene expression at different stages of skeletal myogenesis. J. Biol. Chem. 2007, 282, 6564-6570. [CrossRef] [PubMed]

32. Mallappa, C.; Nasipak, B.T.; Etheridge, L.; Androphy, E.J.; Jones, S.N.; Sagerstrom, C.G.; Ohkawa, Y.; Imbalzano, A.N. Myogenic microrna expression requires atp-dependent chromatin remodeling enzyme function. Mol. Cell Biol. 2010, 30, 3176-3186. [CrossRef] [PubMed]

33. Meggio, F.; Pinna, L.A. One-thousand-and-one substrates of protein kinase ck2? Faseb J. 2003, 17, 349-368. [CrossRef] [PubMed]

34. Litchfield, D.W. Protein kinase ck2: Structure, regulation and role in cellular decisions of life and death. Biochem. J. 2003, 369, 1-15. [CrossRef]

35. Nunez de Villavicencio-Diaz, T.; Rabalski, A.J.; Litchfield, D.W. Protein kinase ck2: Intricate relationships within regulatory cellular networks. Pharmaceuticals 2017, 10, 27. [CrossRef]

36. Seldin, D.C.; Lou, D.Y.; Toselli, P.; Landesman-Bollag, E.; Dominguez, I. Gene targeting of ck2 catalytic subunits. Mol. Cell. Biochem. 2008, 316, 141-147. [CrossRef]

37. Lou, D.Y.; Dominguez, I.; Toselli, P.; Landesman-Bollag, E.; O’Brien, C.; Seldin, D.C. The alpha catalytic subunit of protein kinase ck2 is required for mouse embryonic development. Mol. Cell Biol. 2008, 28, 131-139. [CrossRef]

38. Xu, X.; Toselli, P.A.; Russell, L.D.; Seldin, D.C. Globozoospermia in mice lacking the casein kinase ii alpha' catalytic subunit. Nat. Genet. 1999, 23, 118-121. [CrossRef]

39. Buchou, T.; Vernet, M.; Blond, O.; Jensen, H.H.; Pointu, H.; Olsen, B.B.; Cochet, C.; Issinger, O.G.; Boldyreff, B. Disruption of the regulatory beta subunit of protein kinase $\mathrm{ck} 2$ in mice leads to a cell-autonomous defect and early embryonic lethality. Mol. Cell Biol. 2003, 23, 908-915. [CrossRef]

40. Pepperkok, R.; Lorenz, P.; Jakobi, R.; Ansorge, W.; Pyerin, W. Cell growth stimulation by egf: Inhibition through antisense-oligodeoxynucleotides demonstrates important role of casein kinase ii. Exp. Cell Res. 1991, 197, 245-253. [CrossRef]

41. Lorenz, P.; Pepperkok, R.; Ansorge, W.; Pyerin, W. Cell biological studies with monoclonal and polyclonal antibodies against human casein kinase ii subunit beta demonstrate participation of the kinase in mitogenic signaling. J. Biol. Chem. 1993, 268, 2733-2739.

42. Pepperkok, R.; Lorenz, P.; Ansorge, W.; Pyerin, W. Casein kinase ii is required for transition of g0/g1, early g1, and g1/s phases of the cell cycle. J. Biol. Chem. 1994, 269, 6986-6991. [PubMed]

43. Lorenz, P.; Pepperkok, R.; Pyerin, W. Requirement of casein kinase 2 for entry into and progression through early phases of the cell cycle. Cell. Mol. Biol. Res. 1994, 40, 519-527. [PubMed]

44. Gotz, C.; Montenarh, M. Protein kinase ck2 in development and differentiation. Biomed. Rep. 2017, 6, 127-133. [CrossRef] [PubMed]

45. Winter, B.; Kautzner, I.; Issinger, O.G.; Arnold, H.H. Two putative protein kinase ck2 phosphorylation sites are important for myf-5 activity. Biol. Chem. 1997, 378, 1445-1456. [CrossRef] [PubMed] 
46. Johnson, S.E.; Wang, X.; Hardy, S.; Taparowsky, E.J.; Konieczny, S.F. Casein kinase ii increases the transcriptional activities of mrf4 and myod independently of their direct phosphorylation. Mol. Cell Biol. 1996, 16, 1604-1613. [CrossRef]

47. Dietz, K.N.; Miller, P.J.; Hollenbach, A.D. Phosphorylation of serine 205 by the protein kinase ck2 persists on pax3-foxo1, but not pax3, throughout early myogenic differentiation. Biochemistry 2009, 48, 11786-11795. [CrossRef]

48. Dietz, K.N.; Miller, P.J.; Iyengar, A.S.; Loupe, J.M.; Hollenbach, A.D. Identification of serines 201 and 209 as sites of pax3 phosphorylation and the altered phosphorylation status of pax3-foxo1 during early myogenic differentiation. Int. J. Biochem. Cell Biol. 2011, 43, 936-945. [CrossRef]

49. Iyengar, A.S.; Loupe, J.M.; Miller, P.J.; Hollenbach, A.D. Identification of ck2 as the kinase that phosphorylates pax3 at ser209 in early myogenic differentiation. Biochem. Biophys. Res. Commun. 2012, 428, 24-30. [CrossRef]

50. Dick, S.A.; Chang, N.C.; Dumont, N.A.; Bell, R.A.; Putinski, C.; Kawabe, Y.; Litchfield, D.W.; Rudnicki, M.A.; Megeney, L.A. Caspase 3 cleavage of pax7 inhibits self-renewal of satellite cells. Proc. Natl. Acad. Sci. USA 2015, 112, E5246-E5252. [CrossRef]

51. Gonzalez, N.; Moresco, J.J.; Cabezas, F.; de la Vega, E.; Bustos, F.; Yates, J.R., 3rd; Olguin, H.C. Ck2-dependent phosphorylation is required to maintain pax7 protein levels in proliferating muscle progenitors. PLOS ONE 2016, 11, e0154919. [CrossRef] [PubMed]

52. Miller, P.J.; Dietz, K.N.; Hollenbach, A.D. Identification of serine 205 as a site of phosphorylation on pax3 in proliferating but not differentiating primary myoblasts. Protein Sci. 2008, 17, 1979-1986. [CrossRef] [PubMed]

53. Seale, P.; Sabourin, L.A.; Girgis-Gabardo, A.; Mansouri, A.; Gruss, P.; Rudnicki, M.A. Pax7 is required for the specification of myogenic satellite cells. Cell 2000, 102, 777-786. [CrossRef]

54. Oustanina, S.; Hause, G.; Braun, T. Pax7 directs postnatal renewal and propagation of myogenic satellite cells but not their specification. EMBO J. 2004, 23, 3430-3439. [CrossRef]

55. Buckingham, M.; Bajard, L.; Daubas, P.; Esner, M.; Lagha, M.; Relaix, F.; Rocancourt, D. Myogenic progenitor cells in the mouse embryo are marked by the expression of pax3/7 genes that regulate their survival and myogenic potential. Anat. Embryol. 2006, 211, 51-56. [CrossRef]

56. Zammit, P.S.; Relaix, F.; Nagata, Y.; Ruiz, A.P.; Collins, C.A.; Partridge, T.A.; Beauchamp, J.R. Pax7 and myogenic progression in skeletal muscle satellite cells. J. Cell Sci. 2006, 119, 1824-1832. [CrossRef]

57. Relaix, F.; Montarras, D.; Zaffran, S.; Gayraud-Morel, B.; Rocancourt, D.; Tajbakhsh, S.; Mansouri, A.; Cumano, A.; Buckingham, M. Pax3 and pax7 have distinct and overlapping functions in adult muscle progenitor cells. J. Cell Biol. 2006, 172, 91-102. [CrossRef]

58. Cornelison, D.D.; Wold, B.J. Single-cell analysis of regulatory gene expression in quiescent and activated mouse skeletal muscle satellite cells. Dev. Biol. 1997, 191, 270-283. [CrossRef]

59. Shi, X.; Seldin, D.C.; Garry, D.J. Foxk1 recruits the sds3 complex and represses gene expression in myogenic progenitors. Biochem. J. 2012, 446, 349-357. [CrossRef]

60. Cheusova, T.; Khan, M.A.; Schubert, S.W.; Gavin, A.C.; Buchou, T.; Jacob, G.; Sticht, H.; Allende, J.; Boldyreff, B.; Brenner, H.R.; et al. Casein kinase 2-dependent serine phosphorylation of musk regulates acetylcholine receptor aggregation at the neuromuscular junction. Genes Dev. 2006, 20, 1800-1816. [CrossRef]

61. Salizzato, V.; Zanin, S.; Borgo, C.; Lidron, E.; Salvi, M.; Rizzuto, R.; Pallafacchina, G.; Donella-Deana, A. Protein kinase ck2 subunits exert specific and coordinated functions in skeletal muscle differentiation and fusogenic activity. FASEB J. 2019, fj201801833RR. [CrossRef] [PubMed]

62. Motohashi, N.; Asakura, A. Muscle satellite cell heterogeneity and self-renewal. Front. Cell Dev. Biol 2014, 2, 1. [CrossRef] [PubMed]

63. Montarras, D.; L'Honore, A.; Buckingham, M. Lying low but ready for action: The quiescent muscle satellite cell. FEBS J. 2013, 280, 4036-4050. [CrossRef] [PubMed]

64. Brack, A.S.; Rando, T.A. Tissue-specific stem cells: Lessons from the skeletal muscle satellite cell. Cell Stem Cell 2012, 10, 504-514. [CrossRef] [PubMed]

65. Chang, N.C.; Rudnicki, M.A. Satellite cells: The architects of skeletal muscle. Curr. Top. Dev. Biol. 2014, 107, 161-181. [PubMed]

66. Kuang, S.; Charge, S.B.; Seale, P.; Huh, M.; Rudnicki, M.A. Distinct roles for pax7 and pax3 in adult regenerative myogenesis. J. Cell Biol. 2006, 172, 103-113. [CrossRef] [PubMed] 
67. Sif, S.; Stukenberg, P.T.; Kirschner, M.W.; Kingston, R.E. Mitotic inactivation of a human swi/snf chromatin remodeling complex. Genes Dev. 1998, 12, 2842-2851. [CrossRef]

68. Muchardt, C.; Reyes, J.C.; Bourachot, B.; Leguoy, E.; Yaniv, M. The hbrm and brg-1 proteins, components of the human snf/swi complex, are phosphorylated and excluded from the condensed chromosomes during mitosis. EMBO J. 1996, 15, 3394-3402. [CrossRef]

69. Jordan, M.A.; Thrower, D.; Wilson, L. Effects of vinblastine, podophyllotoxin and nocodazole on mitotic spindles. Implications for the role of microtubule dynamics in mitosis. J. Cell Sci. 1992, 102, 401-416.

70. Sarno, S.; Reddy, H.; Meggio, F.; Ruzzene, M.; Davies, S.P.; Donella-Deana, A.; Shugar, D.; Pinna, L.A. Selectivity of 4,5,6,7-tetrabromobenzotriazole, an atp site-directed inhibitor of protein kinase ck2 ('casein kinase-2'). Febs Lett. 2001, 496, 44-48. [CrossRef]

71. Puri, P.L.; Mercola, M. BAF60 a, b, and cs of muscle determination and renewal. Genes Dev. 2012, 26, 2673-2683. [CrossRef] [PubMed]

72. Kinoshita, E.; Kinoshita-Kikuta, E.; Koike, T. Phosphate-affinity gel electrophoresis using a phos-tag molecule for phosphoproteome study. Curr. Proteom. 2009, 9. [CrossRef]

73. Horinouchi, T.; Terada, K.; Higashi, T.; Miwa, S. Using phos-tag in western blotting analysis to evaluate protein phosphorylation. Methods Mol. Biol 2016, 1397, 267-277. [PubMed]

74. Kinoshita, E.; Kinoshita-Kikuta, E.; Takiyama, K.; Koike, T. Phosphate-binding tag, a new tool to visualize phosphorylated proteins. Mol. Cell. Proteom. 2006, 5, 749-757. [CrossRef]

75. Reyes, J.C.; Muchardt, C.; Yaniv, M. Components of the human swi/snf complex are enriched in active chromatin and are associated with the nuclear matrix. J. Cell Biol. 1997, 137, 263-274. [CrossRef]

76. Zhao, K.; Wang, W.; Rando, O.J.; Xue, Y.; Swiderek, K.; Kuo, A.; Crabtree, G.R. Rapid and phosphoinositol-dependent binding of the swi/snf-like BAF complex to chromatin after tymphocyte receptor signaling. Cell 1998, 95, 625-636. [CrossRef]

77. Fawcett, D.W. An Atlas of Fine Structure: The Cell, Its Organelles and Inclusions; W. B. Saunders Co: Philadelphia, PA, USA, 1966; p. 448.

78. Vogelstein, B.; Pardoll, D.M.; Coffey, D.S. Supercoiled loops and eucaryotic DNA replicaton. Cell 1980, 22, 79-85. [CrossRef]

79. Nickerson, J.A.; Blencowe, B.J.; Penman, S. The architectural organization of nuclear metabolism. Int. Rev. Cytol. 1995, 162A, 67-123.

80. Razin, S.V.; Iarovaia, O.V.; Vassetzky, Y.S. A requiem to the nuclear matrix: From a controversial concept to 3d organization of the nucleus. Chromosoma 2014, 123, 217-224. [CrossRef]

81. He, D.C.; Nickerson, J.A.; Penman, S. Core filaments of the nuclear matrix. J. Cell Biol. 1990, 110, 569-580. [CrossRef]

82. Dallas, P.B.; Yaciuk, P.; Moran, E. Characterization of monoclonal antibodies raised against p300: Both p300 and cbp are present in intracellular tbp complexes. J. Virol. 1997, 71, 1726-1731. [CrossRef] [PubMed]

83. Bultman, S.; Gebuhr, T.; Yee, D.; La Mantia, C.; Nicholson, J.; Gilliam, A.; Randazzo, F.; Metzger, D.; Chambon, P.; Crabtree, G.; et al. A brg1 null mutation in the mouse reveals functional differences among mammalian swi/snf complexes. Mol. Cell 2000, 6, 1287-1295. [CrossRef]

84. Imbalzano, K.M.; Cohet, N.; Wu, Q.; Underwood, J.M.; Imbalzano, A.N.; Nickerson, J.A. Nuclear shape changes are induced by knockdown of the swi/snf atpase brg1 and are independent of cytoskeletal connections. PLoS ONE 2013, 8, e55628. [CrossRef] [PubMed]

85. Barutcu, A.R.; Lajoie, B.R.; Fritz, A.J.; McCord, R.P.; Nickerson, J.A.; van Wijnen, A.J.; Lian, J.B.; Stein, J.L.; Dekker, J.; Stein, G.S.; et al. Smarca4 regulates gene expression and higher-order chromatin structure in proliferating mammary epithelial cells. Genome Res. 2016, 26, 1188-1201. [CrossRef]

86. Barutcu, A.R.; Lian, J.B.; Stein, J.L.; Stein, G.S.; Imbalzano, A.N. The connection between brg1, ctcf and topoisomerases at tad boundaries. Nucleus 2017, 8, 150-155. [CrossRef]

87. Imbalzano, A.N.; Imbalzano, K.M.; Nickerson, J.A. Brg1, a swi/snf chromatin remodeling enzyme atpase, is required for maintenance of nuclear shape and integrity. Commun. Integr. Biol. 2013, 6, e25153. [CrossRef]

88. Naumova, N.; Imakaev, M.; Fudenberg, G.; Zhan, Y.; Lajoie, B.R.; Mirny, L.A.; Dekker, J. Organization of the mitotic chromosome. Science 2013, 342, 948-953. [CrossRef]

89. Gibcus, J.H.; Samejima, K.; Goloborodko, A.; Samejima, I.; Naumova, N.; Nuebler, J.; Kanemaki, M.T.; Xie, L.; Paulson, J.R.; Earnshaw, W.C.; et al. A pathway for mitotic chromosome formation. Science 2018, 359. [CrossRef] 
90. Stukenberg, P.T.; Lustig, K.D.; McGarry, T.J.; King, R.W.; Kuang, J.; Kirschner, M.W. Systematic identification of mitotic phosphoproteins. Curr. Biol. 1997, 7, 338-348. [CrossRef]

91. Bischoff, R.; Heintz, C. Enhancement of skeletal muscle regeneration. Dev. Dyn. 1994, 201, 41-54. [CrossRef]

92. Tintignac, L.A.; Sirri, V.; Leibovitch, M.P.; Lecluse, Y.; Castedo, M.; Metivier, D.; Kroemer, G.; Leibovitch, S.A. Mutant myod lacking cdc2 phosphorylation sites delays m-phase entry. Mol. Cell Biol. 2004, 24, 1809-1821. [CrossRef] [PubMed]

93. Magdalena, J.; Millard, T.H.; Machesky, L.M. Microtubule involvement in nih $3 \mathrm{t} 3$ golgi and mtoc polarity establishment. J. Cell Sci. 2003, 116, 743-756. [CrossRef] [PubMed]

94. Choi, H.J.; Fukui, M.; Zhu, B.T. Role of cyclin b1/cdc2 up-regulation in the development of mitotic prometaphase arrest in human breast cancer cells treated with nocodazole. PLoS ONE 2011, 6, e24312. [CrossRef] [PubMed]

95. Wee, P.; Wang, Z. Cell cycle synchronization of hela cells to assay egfr pathway activation. Methods Mol. Biol. 2017, 1652, 167-181.

96. Runkle, E.A.; Sundstrom, J.M.; Runkle, K.B.; Liu, X.; Antonetti, D.A. Occludin localizes to centrosomes and modifies mitotic entry. J. Biol. Chem. 2011, 286, 30847-30858. [CrossRef]

(C) 2020 by the authors. Licensee MDPI, Basel, Switzerland. This article is an open access article distributed under the terms and conditions of the Creative Commons Attribution (CC BY) license (http://creativecommons.org/licenses/by/4.0/). 